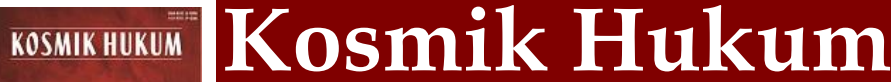

\author{
Fakultas Hukum
}

Universitas Muhammadiyah Purwokerto

Vol. 19 No. 2 (2019)

This work is licensed under a Creative Commons Attribution 4.0 International License (cc-by)

\section{Pemenuhan Hak Politik Penyandang Disabilitas Mental dalam Pemilihan Umum}

\author{
Rizkon Maulana ${ }^{凶}$, Indriati Amarini, Ika Ariani Kartini \\ Fakultas Hukum, Universitas Muhammadiyah Purwokerto \\ E-mail: rizqon.maulana.52@gmail.com
}

\begin{abstract}
The fulfillment of political rights for persons with mental disabilities in general elections has not been running as it should be. Pros and cons arise when collecting data on citizens who have the right to vote at the time of general elections. This research analyzes how the fulfillment of the political rights of persons with mental disabilities in legislation and the obstacles experienced in fulfilling the political rights of persons with mental disabilities. This research is a normative juridical study using secondary data as the main data, namely books, journals, research results, and legislation. Secondary data were analyzed normatively qualitative. The results showed that the political rights of persons with disabilities, including persons with mental disabilities, are a component of human rights that must be fulfilled in a democratic country. The fulfillment of the political rights of persons with disabilities is generally based on Law Number 8 of 2016, namely Article 13 which stipulates that persons with disabilities have the political right to vote and be elected in public office. These rights are important to be respected, protected and fulfilled in order to achieve justice for eliminating political discrimination against persons with disabilities. As for the obstacles experienced in fulfilling the political rights of persons with mental disabilities, namely the difficulty in conveying socialization materials to persons with mental disabilities and the level of voter participation among persons with mental disabilities is still low.
\end{abstract}

Keywords: Political Rights, General Election, Mental Disability

\begin{abstract}
Abstrak
Pemenuhan Hak politik bagi penyandang disabilitas mental pada pemilihan umum belum berjalan sebagaimana seharusnya. Pro dan kontra muncul pada saat pendataan warga yang berhak memberikan hak pilih pada saat pemilihan umum. Penelitian ini menganalisis bagaimana pemenuhan hak politik penyandang disabilitas mental dalam perundang-undangan dan hambatan-hambatan yang dialami dalam pemenuhan hak politik penyandang disabilitas mental. Penelitian ini merupakan penelitian yuridis normative dengan menggunakan data sekunder sebagai data pokok yaitu buku-buku, jurnal, hasil penelitian, dan perundang-undangan. Data sekunder dianalisis secara normatif kualitatif. Hasil penelitian menunjukkan hak politik penyandang disabilitas termasuk penyandang disabilitas mental merupakan salah satu komponen dari Hak Asasi Manusia yang harus dipenuhi dalam negara demokrasi. Pemenuhan hak politik penyandang disabilitas secara umum didasarkan pada Undangundang Nomor 8 Tahun 2016 yaitu dalam Pasal 13 yang menentukan bahwa penyandang disabilitas mempunyai hak politik untuk memilih dan dipilih dalam jabatan publik. Hak tersebut penting untuk dihormati, dilindungi, dan dipenuhi demi terwujudnya keadilan penghapusan diskriminasi politik terhadap penyandang disabilitas. Adapun hambatan-hambatan yang dialami dalam pemenuhan hak politik penyandang disabilitas mental yaitu kesulitan menyampaikan materi sosialisasi kepada penyandang disabilitas mental dan tingkat partisipasi pemilih dikalangan disabilitas mental masih rendah.
\end{abstract}

Kata Kunci: Hak Politik, Pemilihan umum, Disabilitas Mental

Copyright@2019KosmikHukum. All rights reserved.

\section{Pendahuluan}

Hak asasi manusia adalah hak-hak dasar yang dimiliki oleh setiap manusia semata-mata karena ia manusia. Hak ini dimilikinya bukan diberikan oleh masyarakat atau berdasarkan hukum positif, melainkan berdasarkan martabatnya sebagai manusia. ${ }^{1}$ Dalam arti ini, meskipun setiap orang terlahir dengan warna kulit, jenis kelamin, bahasa, budaya dan

Jack Donnely, Universal Human Rights in Theory and Practice(London, Cornell University Press, 2003), 7-21. 
kewarganegaraan yang berbeda-beda, tetap mempunyai hak-hak tersebut. Inilah sifat universal dari HAM. Hak-hak tersebut tidak dapat dicabut (inalienable) oleh siapapun dan kapanpun. ${ }^{2}$ Dalam pandangan ilmu hukum dikenal konsep Equality Before The Law yang menegaskan bahwa setiap orang mempunyai kedudukan yang sama di hadapan hukum serta harus dihindarkan dari adanya deskriminasi. ${ }^{3}$ Sebagaimana disebutkan didalam pasal 27 ayat (1) Undang-Undang Dasar Negara Republik Indonesia 1945 yang menyebutkan bahwa semua warga negara bersamaan kedudukannya didalam hukum dan pemerintahan. Kemudian bukan sekedar warga negara, dalam pasal 28D ayat (1) dan ayat (3) UUD NRI 1945 menyebutkan bahwa "Setiap orang berhak atas pengakuan, jaminan, perlindungan dan kepastian hukum yang adil serta perlakuan yang sama dihadapan hukum dan setiap warga negara berhak memperoleh kesempatan yang sama dalam pemerintahan". Artinya setiap warga negara Indonesia dan setiap orang yang berada didalam wilayah hukum Indonesia memiliki hak-hak yang dijamin secara konstitusional oleh negara.

Konsep Equality Before the Law merupakan konsep untuk melawan diskriminasi. Berkaitan dengan hak dasar yang dimiliki setiap individu tanpa terkecuali ini kemudian mengharuskan setiap individu untuk menghormati, melaksanakan dan mendapat hak tersebut tanpa mengganggu, melanggar apalagi sampai merampas hak-hak orang lain. ${ }^{4}$ Sebagai hak dasar, Hak Asasi Manusia memiliki ruang lingkup yang sangat kompleks. Di Indonesia sendiri garis besar hak-hak yang terangkum dalam Hak Asasi Manusia diantaranya adalah hak-hak asasi politik atau dikenal dengan political rights yang memberikan ruang seluas-luasnya bagi setiap warga negara untuk ikut serta dalam pemerintahan, menggunakan hak pilih dan hak dipilihnya dalam pemilu serta hak untuk bergabung serta mendirikan partai politik tertentu ${ }^{5}$. Hal tersebut juga dijelaskan dalam Pasal 23 ayat (1), serta Pasal 43 Undang-Undang Nomor 39 Tahun 1999 tentang Hak Asasi Manusia.

Berdasarkan data Komisi Pemilihan Umum daftar pemilih menurut hasil rekapitulasi daftar pemilih hasil perbaikan ke-3 (DPTHP-3) pada pemilu 2019 adalah 192.866.254 pemilih'. Komisioner Komisi Pemilihan Umum RI, Pramono Ubaid menyampaikan informasinya bahwa terdapat pemilih disabilitas di DPT Pemilu 2019 sementara sebanyak 363.200 atau 0,191\% dari DPT. Sebanyak 0,029\% pemilih adalah pemilih disabilitas mental, jumlahnya 54.295 orang. ${ }^{7}$ Pada kesempatan lain Ketua Komisi Pemilihan Umum Republik Indonesia Arief Budiman menyampaikan bahwa rekapitulasi Daftar Pemilih Tetap Hasil Perbaikan ke-2 (DPTHP-2) Pemilu 2019 di Indonesia, total DPT berjumlah 192.828.520 pemilih dengan rincian 190.770.329 merupakan pemilih di dalam negeri dan 2.058.191 merupakan pemilih di luar negeri. Dari data tersebut terdapat 1.247 .730 pemilih penyandang disabilitas dengan rincian pemilih tunadaksa mencapai 83.182 orang, tunanetra sebanyak 166.364 pemilih, dan tunarungu sebanyak 249.546 orang. Selain itu, tunagrahita (Disabilitas Intelektual \& Disabilitas Mental) sebanyak 332.728 orang, dan disabilitas yang masuk kategori lainnya sebanyak 415.910 pemilih. ${ }^{8}$ Data Riskesdas Tahun 2013-2018 menunjukkan prevalensi ganggunan mental emosional yang ditunjukkan dengan gejala-gejala depresi dan kecemasan untuk usia 15 tahun ke atas mencapai sekitar 14 juta orang atau $6 \%$ dari jumlah penduduk Indonesia. Sedangkan prevalensi gangguan jiwa

2 Rhona K. M. Smith, dkk., dalam Knut D. Asplund, Suparman Marzuki, Eko Riyadi (editor), Hukum Hak Asasi Manusia, (Yogyakarta: Pusat Studi Hak Asasi Manusia Universitas Islam Indonesia, Yogyakarta, 2010$), 11$.

A Patra M. Zen dan Daniel Hutagalung, Panduan Bantuan Hukum Di Indonesia, (Jakarta: YLBHI dan PSHK, 2006 ), 47.

4 Anwar Harjono, Perjalana Politik Bangsa: Menoleh ke Belakang Menatap Masa Depan, (Jakarta: Gema Insani Press, 1997), 147.

5 Khoirul Anam, Pendidikan Pancasila Kewarganegaraaan untuk Mahasiswa, (Jogjakarta : Inti media, 2011), 194.

6 Dwi Andayani, "KPU: DPT Pemilu Hasil Perbaikan Bertambanh menjadi 192 Juta Orang Lebih", Tersedia di https://news.detik.com/berita/d-4501983/kpu-dpt-pemilu-hasil-perbaikan-bertambah-jadi-192-juta-oranglebih?_ga=2.77357333.1664103743.1572327657-740731782.1571118551

7 Indah Mutiara Kami, "KPU: Bukan 13 Juta Pemilih Disabilitas Mental Hanya 54.295 Orang”, Tersedia di https://news.detik.com/berita/d-4523425/kpu-bukan-13-juta-pemilih-disabilitas-mental-hanya-54295-orang

8 CNN Indonesai, "KPU Sebut Pemilih Penyandang Disabilitas Capai 12 Juta Orang", Tersedia di https://www.cnnindonesia.com/nasional/20181216001650-32-353978/kpu-sebut-pemilih-penyandang-disabilitascapai-12-juta-orang 
berat, seperti skizofrenia mencapai sekitar 400.000 orang atau sebanyak 1,7 per 1.000 penduduk. ${ }^{9}$

Sebagaimana diatur dalam ketentuan Pasal 13 Undang-Undang Nomor 8 Tahun 2016 tentang Penyandang Disabilitas, penyandang disabilitas termasuk penyandang disabilitas mental mempunyai hak politik untuk memilih dan dipilih dalam jabatan publik. Hak tersebut penting untuk dihormati, dilindungi, dan dipenuhi demi terwujudnya keadilan penghapusan diskriminasi politik terhadap penyandang disabilitas. ${ }^{10}$

\section{Rumusan Masalah}

Berdasarkan uraian yang telah dipaparkan diatas, tulisan ini menganalisis tentang bagaimana pemenuhan hak politik penyandang disabilitas khususnya disabilitas mental dan bagaimana hambatan-hambatan yang dialami dalam pemenuhan hak politik penyandang disabilitas mental.

\section{Metodologi Penelitian}

Metode dalam penelitian ini adalah menggunakan metode yuridis normatif. Metode yuridis normatif dilakukan melalui studi pustaka yang menelaah terutama data sekunder yang berupa Peraturan Perundang-undangan, putusan pengadilan, perjanjian, kontrak, atau dokumen hukum lainnya, serta hasil penelitian, hasil pengkajian, dan referensi lainnya. ${ }^{11}$ Data dalam penelitian ini diperoleh melalui Penelitian Kepustakaan (Library Research) Penelitian kepustakaan ini dilakukan untuk mendapatkan data sekunder yang antara lain bahan hukum primer, sekunder, dan tersier dengan melalui seragkaian kegiatan membaca, mencatat, dan mengutip buku-buku serta menggunakan data atau informasi dan keterangan- keterangan melalui permohonan permintaan data pada instansi terkait yang berlandaskan pada tujuan penelitian. Metode yang disusun secara sistematis, logis dan rasional. Dalam hal ini, analisis yang digunakan adalah analisis data kualitatif yaitu data yang tidak bisa diukur atau dinilai dengan angka secara langsung. Dengan demikian maka setelah data primer dan data sekunder berupa dokumen diperoleh lengkap, selanjutnya dianalisis dengan peraturan yang berkaitan dengan masalah yang diteliti. ${ }^{12}$

\section{Hasil Dan Pembahasan}

\section{Pemenuhan hak politik penyandang disabilitas dalam Peraturan Perundang- undangan}

Dalam sejarah perkembangannya, Hak Asasi Manusia saat ini tidak lagi menjadi sebuah konsep ideal dalam menjalankan pemerintahan tetapi Hak Asasi Manusia telah diimplementasikan dalam menjalankan roda pemerintahan. Terlebih ketika berbicara sebagai sebuah negara demokrasi, negara sejatinya merupakan pemangku kewajiban untuk menjamin terselenggaranya hak-hak yang terkandung dalam hak asasi manusia dalam bentuk penghormatan (to respect), perlindungan (to protect) dan pemenuhan (to fullfill) yang berlaku bagi seluruh individu atau warga masyarakat dalam negaranya tanpa adanya perbedaan ataupun diskriminasi. ${ }^{13}$ Keberadaan hak asasi manusia dalam konsepsi negara hukum yang menganut paham demokrasi di Indonesia pada akhirnya menjadi suatu hal yang paling mendasar yang diatur oleh negara. Tingkat implementasi demokrasi dan hak asasi manusia,

\footnotetext{
Kementrian RI, “Hasil Utama Riskesdas 2018”, Badan Penelitian dan Pengembangan Kesehatan, 98-103.

Mugi Riskiana Halalia, Jurnal Supremasi Hukum, 6.2, (2017): 5.

11 Badriyah Khaleed, Legislative Drafting Teori dan Praktik Penyusunan Peraturan Perundang-undangan, (Yogyakarta: Medpress Digital, 2014), 41.

12 Mathew, Miles dan Michel Huberman, Analisis Data Kualitatif : Buku Sumber tentang Metode-metode Baru, (Jakarta : UI Pres, 2009), 102

13 Tony Yuri Rahmanto, Hak Pilih Bagi Penyandang Disabilitas Mental Ditinjau Dari Perspektif Hak Asasi Manusia, Jurnal HAM 10.1, (2019): 29.
} 
dipengaruhi oleh peran negara sehingga implementasi demokrasi dan hak asasi manusia yang berkedaulatan rakyat merupakan cita-cita yang hendak dicapai. ${ }^{14}$

Negara merupakan bentuk dari organisasi kekuasaan, sedangkan kekuasaan cenderungan untuk disalahgunakan. Supaya hal tersebut tidak terjadi, harus diupayakan pencegahan penyalahgunaan kekuasaan dengan mempersiapkan konstitusi atau Undangundang Dasar. Konstitusi atau Undang-Undang Dasar sebagai pemberian pegangan dan pemberi batas, sekaligus tentang bagaimana kekuasaan negara harus dijalankan. Apabila mempelajari konstitusi yang berlaku di setiap negara, didalamnya secara umum selalu terdapat 3 (tiga) kelompok muatan, yaitu ${ }^{15}$ : (1) Pengaturan tentang jaminan dan perlindungan terhadap Hak Asasi Manusia; (2) Pengaturan tentang susunan ketatanegaraan yang bersifat mendasar; (3) Pengaturan tentang pembagian dan pembatasan tugas-tugas ketatanegaraan yang bersifat mendasar.

Hak-hak asasi mencakup hak atas hidup, hak dan kebebasan, dan hak untuk mempunyai milik (life, liberty and property). ${ }^{16}$ Hak-hak politik berkembang sejalan dengan tumbuhnya sistem negara bangsa yang dilembagakan ke dalam sistem parlementer. Hak-hak politik yang berkaitan dengan proses pengambilan keputusan yang diwujudkan dalam bentuk partisipasi dengan memberikan hak pilih pada saat pemilihan berlangsung. ${ }^{17}$ Frans Magnis Suseno menyebutkan bahwa terdapat lima ciri negara demokratis, yaitu negara hukum, pemerintahan yang berada di bawah kontrol masyarakat secara nyata, pemilihan umum yang bebas, prinsip mayoritas, dan adanya jaminan terhadap hak-hak demokratis. ${ }^{18}$ Henry B. Mayo mendefinisikan demokrasi sebagai sistem politik dimana kebijaksanaan umum ditentukan atas dasar mayoritas oleh wakil-wakil yang diawasi secara efektif oleh rakyat dalam pemilihan berkala yang didasarkan atas prinsip kesamaan politik dan diselenggarakan dalam suasana terjaminnya kebebasan politik. ${ }^{19}$ Maka, belumlah dapat dikatakan sempurna apabila sistem demokrasi di suatu negara masih mengesampingkan hak politik dari suatu golongan tertentu.

Sebagaimana konsep persamaan hak antar sesama manusia, Hak Asasi Manusia tidak menghendaki adanya perbedaan terhadap penyandang disabilitas, akan tetapi dalam praktiknya para penyandang disabilitas sering kali menjadi kelompok yang termarjinalkan, mendapat perlakuan yang tidak semestinya dan terhalangi dalam upaya pemenuhan hakhaknnya.Demi tercapainya pemenuhan hak-hak penyandang disabilitas tersebut, perkembangan demi perkembangan terus diikuti oleh Indonesia sebagai negara yang menjunjung tinggi hukum dan HAM mulai dari lahirnya Undang-undang Nomor 4 Tahun 1997 tentang Penyandang Cacat, kemudian seiring berjalannya waktu, sebagai anggota Perserikatan Bangsa-Bangsa Indonesia meratifikasi instrumen internasional Konvenan tentang Hak-Hak Sipil dan Politik melalui Undang-undang Nomor 12 Tahun 2005 tentang Pengesahan International Covenant On Civil And Political Rights (ICCPR), Indonesia juga meratifikasi Konvensi tentang Hak-hak Penyandang Disabilitas (Convention On The Rights Of Persons With Disabilities) melalui Undang-undang Nomor 19 Tahun 2011, dan yang terakhir adalah lahirnya Undang-undang Nomor 8 Tahun 2016 tentang Penyandang Disabilitas.

Perkembangan tersebut memberikan ruang dan jaminan yang lebih luas terhadap pemenuhan hak-hak penyandang disabilitas demi tercapainya keadilan dan peningkatan kesejahteraan bagi penyandang disabilitas. ${ }^{20}$ Selanjutnya berkaitan dengan hak politik

14 Fauzan Khairazi, “Implementasi Demokrasi Dan Hak Asasi Manusia Di Indonesia," Jurnal Inovatif 8.1 (2015): 72-94.

15 Yulia Netta. Partisipasi Masyarakat dalam Penegakan Hak Asasi Manusia. Monograf: Negara Hukum Kesejahteraan. Vol. I. PKKPUU: Fakultas Hukum Universitas Lampung (2013), 50.

16 Jimly Asshidiqie, Pengantar Ilmu Hukum Tata Negara, (Jakarta: Sekretariat Jenderal dan Kepaniteraan M RI, 2006$), 87$.

17 Fuad Fachruddin. Agama dan Pendidikan Demokrasi: Pengalaman Muhammadiyah dan Nadhlatul Ulama. Pustaka Alvabet, 2006), 35-36.

${ }^{18}$ Hendra Nurtcahjo, Filsafat Demokrasi (Jakarta: Bumi Aksara, 2006), 74.

${ }_{19} \mathrm{Ni}^{\prime}$ matul Huda, Politik Ketatanegaraan Indonesia: Kajian Terhadap Dinamika Perubahan UUD 1945 (Jakarta: UI Press, 2003), 57.

20 Mugi Riskiana Halalia, "Pemenuhan Hak Politik Penyandang Disabilitas Sesuai Dengan Undang-Undang Nomor 8 Tahun 2016 tentang Penyandang Disabilitas oleh Komisi Pemilihan Umum (KPU) Kota Yogyakarta", Jurnal Supremasi Hukum, 6.2, (2017): 4. 
penyandang disabilitas juga dijamin oleh pasal 5 Undang-undang Nomor 7 Tahun 2017 tentang Pemilu. Kemudian secara khusus penyandang disbilitas mental atau orang dalam gangguan jiwa juga dijamin haknya melalui Pasal 148 Undang-undang Nomor 36 Tahun 2009 tentang Kesehatan. Berdasarkan serangkaian peraturan perundang-undangan nasional yang telah disebutkan sebelumnya berkaitan dengan hak politik, jelas ditegaskan bahwa tidak ada satupun ketentuan yang bersifat deskriminatif. Perlindungan, penghormatan dan penegakkan hak asasi manusia berdasarkan sifat keuniversalannya akan berhasil jika praktek-praktek marjinalisasi dan deskriminasi terhadap hak-hak suatu kelompok atau individu tertentu telah terhapuskan. Seperti adanya diskriminasi terhadap suatu kelompok yang rentan yang diantaranya adalah perempuan, anak-anak dan penyandang disabilitas. ${ }^{21}$

Undang-undang Dasar Negara Republik Indonesia Tahun 1945 menjamin hak setiap orang atas pengakuan, jaminan, perlindungan, dan kepastian hukum yang adil serta perlakuan yang sama di hadapan hukum. Penyandang Disabilitas menurut Pasal 1 angka 1 UndangUndang Nomor 8 Tahun 2016 tentang Penyandang Disabilitas adalah setiap orang yang mengalami keterbatasan fisik, intelektual, mental, dan/atau sensorik dalam jangka waktu lama yang dalam berinteraksi dengan lingkungan dapat mengalami hambatan dan kesulitan untuk berpartisipasi secara penuh dan efektif dengan warga negara lainnya berdasarkan kesamaan hak. ${ }^{22}$ Pasal 4 ayat (1) Undang-Undang Nomor 8 Tahun 2016 tentang Penyandang Disabilitas menyebutkan bahwa ragam penyandang disabilitas meliputi: a). Penyandang Disabilitas Fisik; b). Penyandang Disabilitas intelektual; c). Penyandang Disabilitas Mental; dan/atau d). Penyandang Disabilitas Sensorik.

Selanjutnya hak politik penyandang disabilitas secara umum diatur dalam Pasal 13 Undang-undang Nomor 8 Tahun 2016 tentang Penyandang Disabilitas, hak politik penyandang disabilitas meliputi: (a) Memilih dan dipilih dalam jabatan publik (b) Menyalurkan aspirasi politik baik tertulis maupun lisan (c) Memilih partai politik dan/atau individu yang menjadi peserta dalam pemilihan umum (d) Membentuk, menjadi anggota dan/atau pengurus organisasi masyarakat dan/atau partai politik (e) Membentuk dan bergabung dalam organisasi penyandang disabilitas dan untuk mewakili Penyandang Disabilitas pada tingkat lokal, nasional, dan Internasional (f) Berperan serta secara efektif dalam sistem pemilihan umum pada semua tahap dan/atau bagian penyelenggaraannya. (g) Memperoleh aksebilitas pada sarana dan prasarana penyelenggaraan pemilihan umum, pemilihan gubernur, bupati/walikota, dan pemilihan kepala desa atau nama lain, dan (h) Memperoleh pendidikan politik

Hak-hak politik penyandang disabilitas sebagaimana diatur Pasal 13 Undang-undang Nomor 8 Tahun 2016 tentang Penyandang Disabilitas di atas penting untuk dihormati, dilindungi, dan dipenuhi demi terwujudnya keadilan penghapusan diskriminasi politik terhadap penyandang disabilitas yang hingga kini menjadi problematika yang belum terselesaikan. Walaupun pemerintah sudah memberikan regulasi yang jelas dan memberikan jaminan terhadap hak-hak penyandang disabilitas melalui serangkaian peraturan perundangundangan. ${ }^{23}$ Adanya hak-hak politik penyandang disabilitas yang tidak terpenuhi tersebut menunjukkan adanya ketimpangan dalam menjalankan sistem hukum negara antara pembentukkan isntrumen hukum (law making) dan penegakkannya (law inforcing). Oleh karena itu, setiap warga negara memiliki hak dan kewajiban terhadap berjalannya pemerintahan dan hal tersebut berlaku sama bagi setiap warga negara, termasuk bagi warga negara penyandang disabilitas. ${ }^{24}$ Secara signifikan tingkat penyaluran hak politik penyandang

21 Mugi Rizkiana Halalia, Pemenuhan Hak Politik Penyandang Disabilitas sesuai dengan Undang-Undang Nomor 8 Tahun 2016 Tentang Penyandang Disabilitas Oleh Komisi Pemilihan Umum Kota Yogyakarta. Skripsi Program Studi Ilmu Hukum Fakultas Syariah dan Hukum Universitas Islam Negeri Sunan Kalijaga, Yogyakarta, (2016).

22 Tersedia di https://www.hukumonline.com/klinik/detail/ulasan/lt5b4eaecedd2db/hak-hak-politik-penyandangdisabilitas

23 Komisi Pemilihan Umum, Tingkat Partisipasi Penyandang Disabilitas PEMILU 2014 di Kota Yogyakarta Capai 66,5\%, Tersedia di http://kpu-jogjakota.go.id/main.php?h=QmVyaXRhSXN p\&i = MTk3

24 Ahmad Sabiq, dkk, "Literasi Politik Kaum Difabel (Studi Kasus Pada Tunanetra di Kabupaten Banjarnegara dalam Pemilu Legislatif dan Pemilu Presiden 2014)," Laporan Riset, Komisi Pemilihan Umum (KPU) Kabupaten Banjarnegara, 2015. 
disabilitas sangat terlihat dalam pemilihan umum. Oleh karena itu, Komisi Pemilihan Umum sebagai penyelenggara Pemilu yang mempunyai tugas dan kewenangan mulai dari perencanaan hingga pelaksanaan sudah sepatutnya menjamin terpenuhinya hak politik setiap warga negara tanpa terkecuali bagi penyandang disabilitas dalam pelaksanaan pemilihan umum. 25

Terkait hak politik penyandang disabilitas termasuk disabilitas mental, Anggota koalisi dari Perhimpunan Jiwa Sehat Indonesia, Yeni Rosa Damayanti menyatakan bahwa ada lima alasan mengapa penyandang disabilitas harus memiliki hak pilih. Pertama, secara filosofis, penyandang disabilitas mental adalah manusia yang memiliki hak asasi yang setara sejak kelahirannya. Salah satu hak asasi manusia yang dimaksud adalah hak politik, khususnya dalam hal ini adalah hak memilih, yang dalam pemenuhannya tidak dapat dibatasi oleh negara, kecuali berdasarkan putusan pengadilan atau Undang-Undang. Kedua, secara yuridis penyandang disabilitas mental adalah Warga Negara Indonesia yang memiliki hak konstitusional yang sama, Pasal 28D ayat (1) Undang-Undang Dasar RI 1945 menyatakan 'Setiap orang berhak atas pengakuan, jaminan, perlindungan, dan kepastian hukum yang adil serta perlakuan yang sama dihadapan hukum'."Ketentuan dalam pasal itu secara tegas melarang adanya pembedaan perlakuan dihadapan hukum, termasuk dalam hal pengaturan mengenai hak memilih. Ketiga, secara medis kapasitas seseorang untuk memilih dalam pemilu tidak ditentukan oleh diagnosis atau gejala yang dialami penderita, melainkan dari kemampuan kognitif (kemampuan berpikir). Anggota koalisi lainnya yang berasal dari Persatuan Penyandang Disabilitas Indonesia, Mahmud Fasa, menambahkan alasan keempat, dari sisi sosiologis dimana perkembangan masyarakat Indonesia, pasca pengesahan UndangUndang Penyandang Disabilitas sudah menuju kepada pembentukan lingkungan yang inklusif. Alasan kelima dilihat dari sisi historis. Dari sisi tersebut, pelarangan hak memilih pada penyandang disabilitas tidak sesuai dengan perkembangan HAM secara internasional karena Perkembangan Hak Asasi Manusia internasional cenderung menjamin hak politik bagi penyandang disabilitas. ${ }^{26}$ Sebagaimana pendapat yang disampaikan oleh Yeni Rosa bahwa penyandang disabilitas mental seharusnya tetap diberikan hak-haknya sesuai dengan peraturan perundang-undangan yang berlaku.

Orang dalam gangguan jiwa atau disabilitas mental yang dalam istilah sehari-hari dikenal dengan gila, miring, dan istilah lainnya. Menurut Pasal 148 Undang-undang Nomor 36 Tahun 2009 tentang Kesehatan, penderita gangguan jiwa mempunyai hak yang sama sebagai warga negara. Hak sebagaimana dimaksud meliputi persamaan perlakuan dalam setiap aspek kehidupan, kecuali peraturan perundang-undangan menyatakan lain. ${ }^{27}$ Secara normatif, dalam penjelasan pasal 4 ayat (1) huruf c Undang-Undang Nomor 8 Tahun 2016 tentang Penyandang Disabilitas menyatakan bahwa penyandang disabilitas mental adalah terganggunya fungsi pikir, emosi, dan perilaku, antara lain: a). psikososial diantaranya skizofrenia, bipolar, depresi, anxietas, dan gangguan kepribadian; dan b). disabilitas perkembangan yang berpengaruh pada kemampuan interaksisosial diantaranya autis dan hiperaktif.

Hukum perdata menempatkan orang dalam gangguan jiwa sebagaimana dalam Pasal 433 Kitab Undang-undang Hukum Perdata bahwa setiap orang dewasa, yang selalu berada dalam keadaan dungu, gila atau mata gelap, harus ditempatkan di bawah pengampuan, sekalipun ia kadang-kadang cakap menggunakan pikirannya. Penetapan bahwa seseorang dinyatakan berada dibawah pengampuan harus berdasarkan putusan pengadilan. Kemudian menurut hukum pidana dalam Pasal 44 Ayat (1) Kitab Undang-undang Hukum Pidana menyatakan bahwa barang siapa melakukan perbuatan yang tidak dapat dipertanggungkan

25 Nadia Rifani Putri, Tomy Michael, “Mengkaji Disabilitas Mental Dalam Hukum Pemilu”, (Surabaya: R.A.De.Rozarie, 2019), 62.

26 Ilham Rian Pratama, "Organisasi Ini Sampaikan 5 Alasan Penyandang Disabilitas Mental Perlu Gunakan Hak Pilih,". Tersedia di https://www.tribunnews.com/nasional/2018/11/24/organisasi-ini-sampaikan-5-alasanpenyandangdisabilitas-mental-perlu-gunakan-hak-pilih

27 Rasyid Rahmat \& Sodikin, "Hak Konstitusional Bagi Penyandang Disabilitas Mental Dalam Pemilihan Umum", Indonesian Constitutional Law Journal 4.1 (2020): 134-135. 
kepadanya karena jiwanya cacat dalam pertumbuhan atau terganggu karena penyakit, tidak dipidana. Menurut kedua pasal di atas dipahami bahwa orang dalam gangguan jiwa sama kedudukannya dengan anak-anak (orang yang belum dewasa) yaitu harus dijaga, dirawat oleh keluarga (harus dalam pengampuan), dan tidak dapat bertindak sendiri dalam melakukan perbuatan hukum. Sebagaimana dijelaskan KUH Perdata Pasal 452 orang yang berada di bawah pengampuan berkedudukan sama dengan anak yang belum dewasa. Kemudian apabila melakukan kejahatan atau tindak pidana orang dalam gangguan jiwa juga tidak dikenai pidana atau hukuman karena tidak ada pertanggungjawaban padanya. ${ }^{28}$

Namun demikian, beberapa dokter ahli jiwa mengatakan hampir semua penjahat menderita penyakit jiwa. Oleh karena mereka tidak mempunyai kecerdasan yang cukup untuk menaati hukum. Mereka yang menderita penyakit jiwa tidak dapat membedakan mana yang baik dan mana yang buruk. Namun harus diketahui bahwa tidak semua orang berpenyakit jiwa melakukan kejahatan. Orang dalam gangguan jiwa tidak memiliki pertanggungjawaban serta tidak sah melakukan perbuatan hukum karena mereka tidak termasuk subjek hukum. CST. Kansil mengatakan bahwa orang yang tidak sehat pikirannya (gila) tidaklah termasuk subyek hukum dan oleh karena itu tidak ada hak-hak dan kewajiban-kewajiban untuk melakukan sesuatu tindakan hukum seperti mengadakan persetujuan-persetujuan, menikah, membuat wasiat dan perbuatan hukum lainnya. ${ }^{29}$ Selanjutnya berdasarkan keterangan pakar psikiatri, disabilitas mental adalah kondisi episodik atau tidak permanen. Meskipun penderita mengalami disabilitas sebagian fungsi mental, mereka tetap bisa hidup normal dan mampu menentukan yang terbaik. ${ }^{30}$

Di Amerika, konstitusi melindungi hak dasar warganegaranya untuk memilih, tetapi sekaligus memberi negara bagian kewenangan untuk menetapkan persyaratan pemberian suara untuk pemilu di tingkat federal maupun negara bagian. Karena itu, masing-masing negara bagian memiliki persyaratan kompetensi memilih yang berbeda-beda. Dari 50 negara bagian, Undang-undang di 39 negara bagian dan ibukota, Washington DC, mengizinkan hakim di pengadilan melucuti hak pilih Penyandang Disabilitas Mental yang dianggap tidak mampu atau tidak kompeten. Definisi kompeten sendiri bervariasi di antara negara bagian, tetapi kompetensi itu ditetapkan oleh pengadilan, bukan petugas dan panitia pemilu atau dokter. Di beberapa negara bagian, ini diketahui sewaktu mengisi formulir registrasi memilih. Seseorang harus menjawab apakah ia pernah dinyatakan tidak mampu secara kejiwaan untuk memilih. Begitu menjawab bahwa dirinya pernah dinyatakan tidak mampu berdasarkan ketetapan pengadilan dan kemampuan ini tidak dipulihkan oleh pengadilan, orang tersebut mau tidak mau dinyatakan tidak layak untuk memlih. ${ }^{31}$

Berbeda dengan Hukum Pidana dan Perdata, Pasal 5 Undang-undang Nomor 7 Tahun 2017 tentang Pemilihan Umum menyebutkan bahwa penyandang disabilitas yang memenuhi syarat mempunyai kesempatan yang sama sebagai pemilih, sebagai calon anggota Dewan Perwakilan Rakyat, sebagai calon anggota Dewan Perwakilan Daerah, sebagai calon presiden/wakil Presiden, sebagai calon anggota Dewan Perwakilan Rakyat Daerah, dan sebagai penyelenggara pemilu. Berdasarkan Undang-undang tersebut jelas menyatakan bahwa Penyandang Disabilitas termasuk Penyandang Disabilitas Mental yang merupakan salah satu bagian didalamnya memiliki hak politik yang sama sebagai warga negara tanpa adanya syarat khusus. Kemudian dengan adanya putusan Mahkamah Konstitusi 135/PUU-XIII/2015 yang telah mencabut ketentuan Pasal 57 ayat (3) huruf a Undang-undang Nomor 8 Tahun 2015, kemudian berdasarkan Undang-undang Nomor 8 Tahun 2016 tentang Penyandang Disabilitas terdapat pada pasal 5 huruf $h$ menjelaskan bahwa penyandang disabilitas memiliki hak politik, 
pada pasal 13 huruf $a$, huruf $c$, huruf $f$ dan huruf g dijelaskan bahwa hak politik penyandang disabilitas meliputi: memilih dan dipilih dalam jabatan publik; memilih partai politik dan/atau individu yang menjadi peserta dalam pemilihan umum; berperan serta secara aktif dalam sistem pemilihan umum pada semua tahap dan/atau bagian penyelenggaraannya; memperoleh aksesibilitas pada sarana dan prasarana penyelenggaraan pemilihan umum, pemilihan gubernur, bupati/walikota, dan pemilihan kepala desa atau nama lain. ${ }^{32}$ Kepastian tersebut kemudian dinyatakan oleh Komisi Pemilihan Umum Republik Indonesia sebagai bentuk realisasi serangkaian peraturan perundang-undangan yang mengatur dan menjamin hak politik penyandang disabilitas, Komisi Pemilihan Umum melalui Surat Edaran Nomor 1401/PL.02.1-SD/01/KPU/ CI/2018 meminta Komisis Pemilihan Umum di semua provinsi dan kabupaten/kota untuk mendata warga negara Indonesia penyandang disabilitas grahita atau gangguan jiwa/mental dan dimasukkan dalam daftar pemilih tetap Pemilihan Umum 2019. Dasar Hukum tersebut semakin memperkuat jaminan atas hak-hak para penyandang disabilitas mental dalam menyalurkan hak politiknya.

Dalam putusan Mahkamah Konstitusi Nomor 135/PUU-XIII/2015 dijelaskan bahwa orang sakit jiwa atau orang gila itu tidak sepenuhnya dia akan sakit jiwa atau gila sampai dia meninggal. Dengan bantuan medis yang tepat, orang yang sakit jiwa atau gila itu bisa saja sudah mengalami kesembuhan dan menjadi orang normal kembali. Yaitu dibuktikan dengan surat keterangan dokter bahwa yang bersangkutan tidak sedang sakit atau tidak disabilitas mental lagi. Untuk mewujudkan tujuan hukum yaitu keadilan, maka penyandang disabilitas mental dapat dicatatkan terlebih dahulu dalam daftar pemilih. Ketika waktu pencoblosan mereka dapat hadir untuk menggunakan hak pilih dengan pendamping atau pengampunya serta membawa keterangan dokter bahwa penyandang disabilitas mental tersebut telah sembuh atau sudah sehat jiwa dan ingatannya. Karena pemilih yang waras mampu memilih pemimpin yang waras. Sehingga keteraturan, ketertiban dan rasa aman bagi masyarakat yang mana semua itu adalah kewajiban negara dapat dipenuhi. ${ }^{33}$

\section{Hambatan-hambatan yang dialami dalam pemenuhan hak politik penyandang disabilitas mental}

Secara yuridis penyandang disabilitas mental berhak untuk memilih dan dipilih dan ikut serta dalam pemilu berdasarkan Putusan MK 135/PUU-XIII/2015, Pasal 13 Poin a UndangUndang Nomor 8 Tahun 2016 Tentang Penyandang Disabilitas, Pasal 5 Undang-Undang Nomor 7 Tahun 2017 tentang pemilu. Kemudian upaya KPU melalui Surat Edaran Nomor 1401/PL.02.1-SD/01/KPU/ CI/2018 meminta Komisi Pemilihan Umum di semua provinsi dan kabupaten/kota untuk mendata warga negara Indonesia penyandang disabilitas grahita atau gangguan jiwa/mental dan dimasukkan dalam daftar pemilih tetap (DPT) Pemilihan Umum (Pemilu) 2019.

Penyandang disabilitas termasuk disabilitas mental sering kesulitan dalam mendapatkan berbagai akses dan kontrol terhadap pembangunan, sumber daya keluarga maupun masyarakat. Hambatan tersebut, dapat diminimalisir melalui kerjasama berbagai pihak yaitu keluarga, masyarakat dan negara (pemerintah). ${ }^{34}$ Upaya yang dilakukan Komisi Pemilihan Umum dalam menjamin pemenuhan hak untuk dipilih selama ini belum tersampaikan kepada para penyandang disabilitas termasuk disabilitas mental didalamnya. Selama ini pihak penyelenggara masih dalam tataran memberikan sosialisasi kepada para penyandang disabilitas dalam hal untuk memilih dan tata cara pemilihan. Hambatan yang muncul dari pihak Komisi Pemilihan Umum adalah kesulitan menyampaikan materi sosialisasi kepada penyandang disabilitas.

32 Rasyid Rahmat \& Sodikin, Hak Konstitusional Bagi Penyandang Disabilitas Mental Dalam Pemilihan Umum, Indonesian Constitutional Law Journal 4.1 (2020): 135-136.

33 Rasyid Rahmat \& Sodikin, op. cit, Indonesian Constitutional Law Journal 4.1 (2020): 138-139.

34 Nadia Rifani Putri, Tomy Michael, "Mengkaji Disabilitas Mental Dalam Hukum Pemilu”, (Surabaya: R.A.De.Rozarie, 2019), 62. 
Dalam meningkatkan partisipasi penyandang disabilitas termasuk disabilitas mental dalam pemilihan umum, pihak penyelenggara tidak bisa bekerja sendiri. Oleh karena itu, diperlukan kerjasama semua pihak baik keluarga dari penyandang disabilitas mental itu sendiri maupun stakeholder lainnya. Aksesibilitas, Selain dari aturan regulasi yang masih menjadi multitafsir baik dikalangan penyandang disabilitas, penyelenggara pemilu kurang dalam sosialisasi (kampanye) ke penyandang disabilitas. Persoalan fasilitas layanan publik terutama pelayanan akses masih sangat jauh dari harapan penyandang disabilitas, sebuah permasalahan yang belum bisa diselesaikan. ${ }^{35}$

\section{Penutup}

\section{Kesimpulan}

Hak politik penyandang disabilitas termasuk disabilitas mental merupakan salah satu komponen dari Hak Asasi Manusia yang harus dipenuhi dalam negara demokrasi. Hak tersebut penting untuk dihormati, dilindungi, dan dipenuhi demi terwujudnya keadilan penghapusan diskriminasi politik terhadap penyandang disabilitas mental. Penyandang disabilitas mental sejatinya adalah orang yang terganggu fungsi pikir, emosi, dan perilakunya yang berdasarkan keterangan pakar psikiatri disabilitas mental adalah kondisi episodik atau tidak permanen. Meskipun penderita mengalami disabilitas sebagian fungsi mental, mereka tetap bisa hidup normal dan mampu menentukan yang terbaik. Keberadaan hak asasi manusia dalam konsepsi negara hukum yang menganut paham demokrasi di Indonesia pada akhirnya menjadi suatu hal yang paling mendasar yang harus dihormati, dilindungi dan dipenuhi tanpa mengesampingkan golongan tertentu. Secara yuridis penyandang disabilitas mental berhak untuk memilih dan dipilih dan ikut serta dalam pemilu berdasarkan Putusan MK 135/PUUXIII/2015, Pasal 13 Poin a Undang-Undang Nomor 8 Tahun 2016 Tentang Penyandang Disabilitas, Pasal 5 Undang-Undang Nomor 7 Tahun 2017 tentang pemilu. Kemudian upaya KPU melalui Surat Edaran Nomor 1401/PL.02.1-SD/01/KPU/ CI/2018 meminta Komisi Pemilihan Umum di semua provinsi dan kabupaten/kota untuk mendata warga negara Indonesia penyandang disabilitas grahita atau gangguan jiwa/mental dan dimasukkan dalam daftar pemilih tetap (DPT) Pemilihan Umum (Pemilu) 2019.

Sebagaimana ketentuan dalam Putusan Mahkamah Konsitusi 135/PUU-XIII/2015, bahwa orang sakit jiwa atau orang gila itu tidak sepenuhnya dia akan sakit jiwa atau gila sampai dia meninggal. Dengan bantuan medis yang tepat, orang yang sakit jiwa atau gila itu bisa saja sudah mengalami kesembuhan dan menjadi orang normal kembali. Yaitu dibuktikan dengan surat keterangan dokter bahwa yang bersangkutan tidak sedang sakit atau tidak disabilitas mental lagi. Untuk mewujudkan tujuan hukum yaitu keadilan, maka penyandang disabilitas mental dapat dicatatkan terlebih dahulu dalam daftar pemilih. Ketika waktu pencoblosan mereka dapat hadir untuk menggunakan hak pilih dengan pendamping atau pengampunya serta membawa keterangan dokter bahwa penyandang disabilitas mental tersebut telah sembuh atau sudah sehat jiwa dan ingatannya. Upaya yang dilakukan Komisi Pemilihan Umum dalam menjamin pemenuhan hak penyandang disabilitas mental sudah tepat melalui Surat Edaran Nomor 1401/PL.02.1-SD/01/KPU/ CI/2018. Namun mengenai hak-hak politik yang dimiliki penyandang disabilitas selama ini belum tersampaikan kepada para penyandang disabilitas termasuk disabilitas mental.

\section{Saran}

Berdasarkan pada kesimpulan diatas maka dapat penulis berikan saran meliputi : Pertama, Negara memfasilitasi sarana dan prasarana serta memberikan ruang yang seluasluasnya dalam mewujudkan hak politik seluruh warga negara termasuk penyandang disabilitas mental. Kedua, Perlu adanya sosialisasi kepada masyarakat, khususnya keluarga dari

35 Marwandianto, "Pelayanan Transportasi Publik Yang Mudah Diakses Oleh Penyandang Disabilitas Dalam Perspektif HAM," Jurnal HAM, 9.2 (2018): 177. 
Kosmik Hukum Vol. 19 No. 2 (2019): 141-150

E-ISSN: 2655-9242 | P-ISSN: 1411-9781

DOI: 10.30595/kosmikhukum.v19i2.8219

penyandang disabilitas mental agar dapat memberikan perhatian berupa pendampingan terhadap anggota keluarga yang menderita disabilitas mental.

\section{Daftar Pustaka}

Anam, Khoirul, Pendidikan Pancasila Kewarganegaraaan untuk Mahasiswa, Jogjakarta : Inti media, 2011

Andayani, Dwi, “KPU: DPT Pemilu Hasil Perbaikan Bertambanh menjadi 192 Juta Orang Lebih", diakses melalui https://news.detik.com/berita/d-4501983/kpu-dpt-pemiluhasil-perbaikan-bertambah-jadi-192-juta-orang-

lebih?_ga=2.77357333.1664103743.1572327657-740731782.1571118551, diakses pada tanggal 02 Juli 2020

Asshidiqie, Jimly, Pengantar Ilmu Hukum Tata Negara, Jakarta: Sekretariat Jenderal dan Kepaniteraan M RI, 2006.

CNN Indonesai, "KPU Sebut Pemilih Penyandang Disabilitas Capai 12 Juta Orang", diakses melalui https://www.cnnindonesia.com/nasional/20181216001650-32-353978/kpusebut-pemilih-penyandang-disabilitas-capai-12-juta-orang

Donnely, Jack, Universal Human Rights in Theory and Practice, Cornell University Press, Ithaca and London, 2003.

Fachruddin, Fuad, Agama dan Pendidikan Demokrasi: Pengalaman Muhammadiyah dan Nadhlatul Ulama. Pustaka Alvabet, 2006.

Fauzan Khairazi, Implementasi Demokrasi Dan Hak Asasi Manusia Di Indonesia, Jurnal Inovatif, 8. no. 1 (2015).

Halalia, Rizkiana, Mugi, Pemenuhan Hak Politik Penyandang Disabilitas Sesuai Dengan Undang-Undang Nomor 8 Tahun 2016 tentang Penyandang Disabilitas oleh Komisi Pemilihan Umum (KPU) Kota Yogyakarta, Jurnal Supremasi Hukum, 6. no. 2, (2017).

Halalia, Rizkiana, Mugi, Pemenuhan Hak Politik Penyandang Disabilitas sesuai dengan Undang-Undang Nomor 8 Tahun 2016 Tentang Penyandang Disabilitas Oleh Komisi Pemilihan Umum Kota Yogyakarta. Skripsi Program Studi Ilmu Hukum Fakultas Syariah dan Hukum Universitas Islam Negeri Sunan Kalijaga, Yogyakarta, 2016.

Harjono, Anwar, Perjalana Politik Bangsa: Menoleh ke Belakang Menatap Masa Depan, Jakarta: Gema Insani Press, 1997.

https://www.hukumonline.com/klinik/detail/ulasan/lt5b4eaecedd2db/hak-hak-politikpenyandang-disabilitas

Hussin, Utami, Komparasi Hak Pilih Penyandang Disabilitas di Amerika Serikat dan Indonesia, diakses melalui https://www.voaindonesia.com/a/komparasi-hak-pilihpenyandang-disabilitas-mental-di-as-dan-indonesia-/4864128.html

Ismail, "Penyandang Disabilitas Mental Harus Difasilitasi Memilih." diakses melalui https://m.tribunnews.com/amp/nasional/2018/perludem-penyandang-disabilitasharus-difasilitasi-memilih

Kami, Mutiara, Indah, "KPU: Bukan 13 Juta Pemilih Disabilitas Mental Hanya 54.295 Orang", diakses melalui https://news.detik.com/berita/d-4523425/kpu-bukan-13-jutapemilih-disabilitas-mental-hanya-54295-orang

Kansil, C.ST., Hukum TataPemerintahan Indonesia, Jakarta: Ghalia Indonesia, 1985.

Kementrian RI, Hasil Utama Riskesdas 2018, Badan Penelitian dan Pengembangan Kesehatan, 2018.

Khaleed, Badriyah, Legislative Drafting Teori dan Praktik Penyusunan Peraturan Perundangundangan, Yogyakarta: Medpress Digital, 2014.

Komisi Pemilihan Umum, Tingkat Partisipasi Penyandang Disabilitas PEMILU 2014 di Kota Yogyakarta Capai $\quad 66,5 \% \quad$ Tersedia di:http://kpujogjakota.go.id/main.php?h=QmVyaXRhSXN p\&i = MTk3 ,

Marwandianto, "Pelayanan Transportasi Publik Yang Mudah Diakses Oleh Penyandang Disabilitas Dalam Perspektif HAM," Jurnal HAM, 9. no.2 (2018). 
Mathew, Miles dan Huberman, Michel, Analisis Data Kualitatif : Buku Sumber tentang Metodemetode Baru, Jakarta : UI Pres, 2009.

Netta, Yulia. Partisipasi Masyarakat dalam Penegakan Hak Asasi Manusia. Monograf: Negara Hukum Kesejahteraan. Vol. I. PKKPUU: Fakultas Hukum Universitas Lampung , 2013.

Ni'matul Huda, Politik Ketatanegaraan Indonesia: Kajian Terhadap Dinamika Perubahan UUD 1945, Jakarta: UI Press, 2003.

Nurtcahjo, Hendra, Filsafat Demokrasi, Jakarta: Bumi Aksara, 2006.

Patra, A, dan Hutagalung, Daniel, Panduan Bantuan Hukum Di Indonesia, Jakarta: YLBHI dan PSHK, 2006.

Pratama, Rian, Ilham, “Organisasi Ini Sampaikan 5 Alasan Penyandang Disabilitas Mental Perlu Gunakan Hak Pilih," Tersedia di https://www.tribunnews.com/nasional/2018/11/24/organisasi-ini-sampaikan-5alasan-penyandangdisabilitas-mental-perlu-gunakan-hak-pilih,

Putri, Rifani, Nadiya, \& Michael, Tomy, Mengkaji Disabilitas Mental Dalam Hukum Pemilu, Surabaya: R.A.De.Rozarie, 2019.

Rahmanto, Yuri, Tony, Hak Pilih Bagi Penyandang Disabilitas Mental Ditinjau Dari Perspektif Hak Asasi Manusia, Jurnal HAM ,10. no. 1, (2019).

Rahmat, Rasyid \& Sodikin, Hak Konstitusional Bagi Penyandang Disabilitas Mental Dalam Pemilihan Umum, Indonesian Constitutional Law Journal, 4. no. 1 (2020).

Sabiq, Ahmad dkk, "Literasi Politik Kaum Difabel (Studi Kasus Pada Tunanetra di Kabupaten Banjarnegara dalam Pemilu Legislatif dan Pemilu Presiden 2014)," Laporan Riset, Komisi Pemilihan Umum (KPU) Kabupaten Banjarnegara, 2015.

Smith, K. M., Rhona, dkk., dalam Knut D. Asplund, Suparman Marzuki, Eko Riyadi (editor), Hukum Hak Asasi Manusia, Pusat Studi Hak Asasi Manusia Universitas Islam Indonesia, Yogyakarta, Cet. Kedua, 2010. 